\title{
PROSPECTS FOR INTERSPECIFIC POTATO HYBRIDS OF VARIOUS RIPENESS IN \\ TERMS OF STARCH CONTENT AND YIELD
}

Podgaietskiy A.A., Kriuchko L.V.

Sumy National agrarian university, Ukraine

The article presents the research results on breeding value of interspecific potato hybrids, which belong to various ripeness groups and were generated with involvement of Mexican wild species, in terms starch content in tubers and starch yield per plant.

The aim and tasks of the study was to evaluate the potential of interspecific hybrids of various ripeness and their backcrosses by starch content, starch yield per plant and the effect of meteorological conditions during the experiment years on trait expression.

Materials and methods. Source material was interspecific hybrids obtained with involvement of three, four, five and six wild and cultivated species. Presence in the origin of S. bulbocastanum species was common to all combinations. They were created by backcrossing, self-pollination at different stages and hybrid crossing between one another.

Results and Discussion. A substantial potential of hybrids and their backcrosses in terms of starch content was proved. Even in 2012, which was very unfavorable for starch formation, a significant portion of the investigated material exceeded values of standard varieties. In 2013 and especially in 2014, which were better for starch formation, there was much more of such material. The proportion of hybrids with the trait level of greater than $22.0 \%$ was $20.0 \%$ and $25.0 \%$ among very late-ripening hybrids, respectively.

Low starch content in early-ripening hybrids in 2012 determined its low yield per plant. All such hybrids were referred to the class of $40.0 \mathrm{~g} / \mathrm{plant}$ value and lower. In the next year, they were presented in two classes, and in 2014 - in three classes, up to $120 \mathrm{~g} /$ plant.

Conclusions. Numerous interspecific hybrids and their backcrosses greatly exceeding the standard varieties by this parameter, which under favorable conditions was greater than $200 \mathrm{~g} / \mathrm{plant}$, were identified. They were also noticeable for breeding value by other traits.

Key words: potato, interspecific hybrids, backcross, starch content, starch yield, meteorological conditions

УДК 633.11,,321”:631.523

\section{ТРАНСГРЕСИВНА МІНЛИВІСТЬ ОЗНАК ПРОДУКТИВНОСТІ ГІБРИДІВ ДРУГОГО ПОКОЛІННЯ ПШЕНИЦ ТВЕРДОЇ ЯРӦ̈}

Хоменко С. О., Федоренко М. В.

Миронівський інститут пшениці імені В. М. Ремесла НААН, Україна

Наведено результати дослідження характеру успадкування ознак продуктивності рослин (довжина колоса, кількість колосків у колосі, кількість зерен з колоса та маса зерна 3 колоса) у другому поколінні гібридів пшениці твердої ярої. Встановлені різні показники коефіцієнта успадковуваності в залежності від ознаки та комбінації схрещування.

Ключові слова: пшениця тверда яра, трансгресія, продуктивність, гібрид

Вступ. Трансгресивна мінливість відноситься до факторів появи у процесі розщеплення гібридів таких гомозиготних за полімерними генами генотипів, які за спектром мінли-

(C) С. О. Хоменко, М. В. Федоренко. 2015.

ISSN 0582-5075. Селекція і насінництво. 2015. Випуск 107. 
вості за фенотипом виходять за межі прояву ознак батьківських форм [1]. Вона $є$ результатом дії і взаємодії багатьох полімерних генів, які контролюють кількісні та якісні ознаки [2].

Аналіз літературних даних, постановка проблеми. У практичному відношенні ряд трансгресій за кількісними ознаками являють цінні варіанти, про які мріють селекціонери, коли хочуть виділити із гібридної популяції біотипи, які за окремими характеристиками або їх комплексом переважають існуючі сорти. Не випадково окремі дослідники приділяють велику увагу трансгресіям, а деякі селекціонери [3] завдяки науково обгрунтованому підходу до виділення трансгресивних морфобіотипів досягли великих успіхів у створенні нових сортів. Аналіз селекційно-генетичних досліджень 3 пшениці показує [2], що генетична природа трансгресій вивчена недостатньо. Вважається [4-6], що причиною трансгресивного розщеплення $є$ об'єднання в гібридному організмі генотипів батьків, які доповнюють один одного окремими генами. Але не відомо, за якого типу взаємодії алелів зумовлюється прояв трансгресій. Крім того методи прогнозування параметрів трансгресії ще не досконалі, а це не дозволяє селекціонерам ефективно використовувати це явище у масовому порядку.

За даними А. П. Орлюка [7], при розщепленні в $F_{2}$ спостерігається значна мінливість ознак, прояв яких є відмінним від батьківських форм. Тому для практичної селекції на продуктивність великого значення набувають позитивні трансгресіі, отримані в результаті появи рекомбінатів за певними господарсько цінними ознаками.

Мета і задачі досліджень передбачала вивчення характеру успадкування ознак продуктивності рослин у другому поколінні гібридів пшениці твердої ярої.

Матеріал та методика. Дослідження проводилися протягом 2014 р. в умовах дослідного поля лабораторії селекції ярої пшениці Миронівського інституту пшениці імені В. М. Ремесла НААН України. Матеріалом для дослідження слугували 10 сортів і сім константних ліній гібридного походження пшениці твердої ярої з різним адаптивним потенціалом та генетичним походженням. На їх основі створено 14 гібридних комбінацій $\mathrm{F}_{2}$, які отримані у результаті внутрішньовидової гібридизації. Насіння гібридів та батьківських форм висівали в гібридному розсаднику за схемою „материнська форма $-\mathrm{F}_{2}$ - батьківська форма" з міжряддям 15 см.

Структурний аналіз рослин та батьківських форм здійснювали індивідуально за ознаками: довжина колоса, кількість колосків і зерен з колоса, маса зерна 3 колоса. Коефіцієнти успадковуваності ознак в широкому $\left(\mathrm{H}^{2}\right)$ розумінні визначали через варіанси батьків і гібридів [8], у вузькому $\left(\mathrm{h}^{2}\right)$ - знаходили через коефіцієнти кореляції між батьками і нащадками [9]. Ступінь (Тc) і частоту (Тч) позитивної трансгресії розраховували за методикою Воскресенської-Шпота [10].

Обговорення результатів. На трансгресивну мінливість ознак найбільше впливає домінантно-гіпостатична взаємодія генів. Трансгресивна мінливість продуктивності колоса істотно залежить від особливостей успадкування ознаки. Якщо в $\mathrm{F}_{2}$ домінантність ознаки зменшується до одиниці, що свідчить про перевагу алельного генетичного контролю ознаки, то в гібридних популяціях вищепляється незначна кількість цінних біотипів (6-10\%). Значну селекційну цінність мають гібриди, у яких в $\mathrm{F}_{1}$ виявляється гетерозис, а в $\mathrm{F}_{2}$ - часткове домінування або проміжне успадкування. У таких гібридів частота трансгресії відносно невисока, але ступінь трансгресій досягає в середньому 30 \%. Великим розмахом формоутворювальних процесів характеризуються гібриди 3 проміжним успадкуванням продуктивності колоса в $\mathrm{F}_{1}$ та $\mathrm{F}_{2}$ [11].

Висока частота позитивної трансгресії спостерігалась за ознакою „довжина колоса” (табл. 1) у внутрішньовидових гібридів: Леукурум 02-03 х Славута (40,0\%), Харківська 27 x Neodur (36,0 \%), Леукурум 06-07 х Саратовская золотистая (32,0 \%), Чадо х Леукурум 0203 (32,0 \%), Саратовская золотистая х Neodur (20,0 \%), Спадщина х Лінія 10-01 (20,0 \%). 
Таблиця 1

Варіювання, ступінь та частота трансгресії довжини колоса у внутрішньовидових гібридів F $_{2}$ пшениці твердої ярої (МII, 2014 р.)

\begin{tabular}{|l|c|c|c|c|c|}
\hline \multicolumn{1}{|c|}{ Комбінація схрещування } & $\mathrm{Max}$ 월 & $\mathrm{X} \pm \mathrm{Sx}$ & $\mathrm{V}, \%$ & $\mathrm{Tc}, \%$ & $\mathrm{~T}, \%$ \\
\hline Леукурум 02-03 х Славута & 6,0 & $7,6 \pm 0,2$ & 7,9 & 33,3 & 40,0 \\
\hline Харківська 27 х Nеodur & 7,0 & $7,9 \pm 0,1$ & 4,2 & 14,3 & 36,0 \\
\hline Леукурум 06-07 х Саратовская золотистая & 7,0 & $8,1 \pm 0,3$ & 13,5 & 42,8 & 32,0 \\
\hline Чадо х Леукурум 02-03 & 8,0 & $9,1 \pm 0,2$ & 8,5 & 25,0 & 32,0 \\
\hline Саратовская золотистая х Neodur & 8,0 & $8,6 \pm 0,3$ & 11,6 & 25,0 & 20,0 \\
\hline Спадщина х Лінія 10-01 & 8,0 & $9,0 \pm 0,3$ & 11,1 & 12,5 & 20,0 \\
\hline Леукурум 06-07 х Харківська 29 & 8,0 & $9,2 \pm 0,3$ & 12,4 & 12,5 & 16,0 \\
\hline Харківська 27 х Леукурум 99-6 & 6,0 & $6,1 \pm 0,2$ & 10,4 & 16,7 & 8,0 \\
\hline Лінія 10-04 х Атmar 9 & 7,0 & $6,6 \pm 0,3$ & 14,4 & 14,3 & 8,0 \\
\hline Леукурум 05-20 х Славута & 8,0 & $7,8 \pm 0,2$ & 7,7 & 12,5 & 8,0 \\
\hline
\end{tabular}

Частота позитивної трансгресії за кількістю колосків у колосі виявилась у 11 (78,6 \%) внутрішньовидових гібридів $\mathrm{F}_{2}$ (табл. 2).

Варіювання, ступінь та частота трансгресії кількості колосків у колосі внутрішньовидових гібридів F $_{2}$ пшениці твердої ярої (МII, 2014 р.)

\begin{tabular}{|c|c|c|c|c|c|}
\hline Комбінація схрещування & $\operatorname{Max} \circ \hat{0}$ & $\mathrm{X} \pm \mathrm{Sx}$ & $\mathrm{V}, \%$ & Tc, $\%$ & Тч, \% \\
\hline Леукурум 06-07 х Саратовская золотистая & 15,0 & $17,3 \pm 0,8$ & 15,3 & 40,0 & 32,0 \\
\hline Харківська 27 x Neodur & 16,0 & $17,1 \pm 0,4$ & 7,6 & 18,8 & 32,0 \\
\hline Леукурум 02-03 х Славута & 18,0 & $18,6 \pm 0,6$ & 10,2 & 11,1 & 16,0 \\
\hline Спадщина х Лінія 10-01 & 19,0 & $19,0 \pm 0,5$ & 8,2 & 10,5 & 16,0 \\
\hline Чадо х Леукурум 02-03 & 20,0 & $19,8 \pm 0,4$ & 6,8 & 5,0 & 16,0 \\
\hline Леукурум 05-20 х Славута & 18,0 & $16,9 \pm 0,6$ & 12,4 & 5,5 & 12,0 \\
\hline Лінія 10-04 x Ammar 9 & 17,0 & $16,4 \pm 0,5$ & 9,0 & 5,8 & 12,0 \\
\hline Ізольда х Леукурум 99-6 & 17,0 & $15,9 \pm 0,7$ & 13,8 & 23,5 & 8,0 \\
\hline Леукурум 06-07 х Харківська 29 & 20,0 & $18,4 \pm 0,6$ & 10,3 & 10,0 & 8,0 \\
\hline
\end{tabular}

За показником „кількість зерен з колоса” (табл. 3) серед матеріалу, що досліджувався, найбільший ступінь позитивної трансгресії було відмічено у внутрішньовидових комбінаціях: Леукурум 06-07 х Саратовская золотистая (44,7 \%), Харківська 27 x Neodur (21,6 \%), Харківська 27 х Леукурум 99-6 (20,0 \%), Спадщина х Лінія 10-01 (16,4%), найнижчий показник - Харківська 37 х Лінія 10-01 (-8,9\%). Частота позитивної трансгресії спостерігалась у 12 (85,7 \%) гібридів другого покоління пшениці твердої ярої з відхиленнями від 4,0 \% до $32,0 \%$.

Таблиця 3

Варіювання, ступінь та частота трансгресії кількості зерен 3 колоса внутрішньовидових гібридів F $_{2}$ пшениці твердої ярої (МIП, 2014 р.)

\begin{tabular}{|l|c|c|c|c|c|}
\hline \multicolumn{1}{|c|}{ Комбінація схрещування } & $\mathrm{Max}$ о & $\mathrm{X} \pm \mathrm{Sx}$ & $\mathrm{V}, \%$ & $\mathrm{Tc}, \%$ & $\mathrm{~T}, \%$ \\
\hline Леукурум 06-07 х Саратовская золотистая & 38,0 & $46,5 \pm 2,2$ & 15,4 & 44,7 & 32,0 \\
\hline Харківська 27 х Neodur & 51,0 & $49,3 \pm 2,3$ & 15,2 & 21,6 & 12,0 \\
\hline Харківська 27 х Леукурум 99-6 & 45,0 & $40,0 \pm 2,7$ & 21,4 & 20,0 & 12,0 \\
\hline Спадщина х Лінія 10-01 & 55,0 & $50,1 \pm 2,6$ & 16,8 & 16,4 & 12,0 \\
\hline Чадо х Леукурум 02-03 & 58,0 & $47,4 \pm 2,7$ & 18,3 & 8,6 & 8,0 \\
\hline Саратовская золотистая х Neodur & 57,0 & $49,2 \pm 2,7$ & 17,9 & 5,2 & 8,0 \\
\hline Лінія 10-04 х Атmar 9 & 47,0 & $38,7 \pm 2,7$ & 22,5 & 4,2 & 8,0 \\
\hline Леукурум 06-07 х Харківська 29 & 58,0 & $48,9 \pm 2,1$ & 13,4 & 3,4 & 8,0 \\
\hline Ізольда х Леукурум 99-6 & 46,0 & $38,6 \pm 1,6$ & 13,2 & 2,2 & 8,0 \\
\hline
\end{tabular}


Ступінь позитивної трансгресії за масою зерна з колоса проявився у 13 (92,8 \%) внутрішньовидових гібридів (табл. 4).

Таблиця 4

Варіювання, ступінь та частота трансгресії маси зерна $з$ колоса внутрішньовидових гібридів F $_{2}$ пшениці твердої ярої (МIП, 2014 р.)

\begin{tabular}{|l|c|c|c|c|c|}
\hline \multicolumn{1}{|c|}{ Комбінація схрещування } & $\mathrm{Max}$ фо & $\mathrm{X} \pm \mathrm{Sx}$ & $\mathrm{V}, \%$ & $\mathrm{Tc}, \%$ & $\mathrm{~T}, \%$ \\
\hline Леукурум 06-07 х Саратовская золотистая & 2,2 & $2,6 \pm 0,1$ & 9,4 & 36,4 & 36,0 \\
\hline Леукурум 02-03 х Славута & 2,4 & $2,5 \pm 0,1$ & 16,0 & 33,3 & 24,0 \\
\hline Харківська 27 х Neodur & 2,5 & $2,6 \pm 0,1$ & 11,5 & 4,0 & 24,0 \\
\hline Харківська 27 х Леукурум 99-6 & 2,2 & $1,9 \pm 0,2$ & 33,3 & 36,4 & 12,0 \\
\hline Леукурум 06-07 х Харківська 29 & 3,1 & $2,8 \pm 0,1$ & 14,3 & 6,5 & 12,0 \\
\hline Лінія 10-04 х Атmar 9 & 2,8 & $2,1 \pm 0,2$ & 28,6 & 7,1 & 8,0 \\
\hline Леукурум 05-20 х Славута & 3,0 & $2,5 \pm 0,1$ & 16,0 & 6,7 & 8,0 \\
\hline Спадщина х Лінія 10-01 & 3,5 & $2,8 \pm 0,2$ & 17,8 & 5,7 & 8,0 \\
\hline Харківська 37 х Лінія 10-01 & 2,7 & $2,1 \pm 0,2$ & 26,1 & 3.7 & 8,0 \\
\hline
\end{tabular}

B $F_{2}$ виділено імовірні трансгресивні форми внутрішньовидових гібридів пшениці твердої ярої, що можуть надалі бути вихідним матеріалом для добору дійсних трансгресивних форм в більш пізніх поколіннях.

При вирішенні селекційних задач важливо знати, як успадковуються в гібридах цінні господарські ознаки. Світовий досвід свідчить про те, що показники успадкування та успадковуваності кількісних ознак у гібридів носить різний, навіть неоднозначний характер. Напевно це можливо пов'язати із залученням в схрещування вихідного матеріалу 3 різною генетичною основою.

Вивчення успадкування, успадковуваності та кореляційних залежностей кількісних ознак у гібридів проводилося рядом вчених. При створенні вихідного матеріалу для селекції самозапильних культур на ознаки продуктивності значну увагу приділяють генетичним особливостям кількісних ознак, які визначають продуктивність рослин [12].

Елементи продуктивності колоса у внутрішньовидових гібридів $\mathrm{F}_{2}$ характеризувались різними показниками коефіцієнта успадковуваності (табл. 5).

Важливим є вивчення успадковуваності довжини колоса. Це дає селекціонеру можливість створення довгоколосих форм з крупним зерном. Встановлено, що довжина колоса контролюється, в основному, генами з адитивною дією, які в деяких випадках проявляють домінування в різній мірі, наддомінуванням та неалельну взаємодію [13]. Показник успадковуваності за довжиною колоса у гібридів варіював від 0,17 до 0,76.

Показник успадковуваності за кількістю зерен з колоса носить дуже різний характер. Деякі вчені $[14,15]$ одержали досить високі показники успадковуваності. Однак інші дослідники [16] наполягають на тому, що дана ознака характеризується низькою успадковуваністю. За даними одних авторів [17] у гібридів першого покоління проявляється гетерозисний ефект, а на думку інших [18] - не проявляється. S. Wegrzyn, L. Pochaba [19], говорячи про успадковуваність ознаки кількість зерен з колоса у зернових, вказують на епістаз. Необхідно відмітити, що при характеристиці в цілому генетичні системи контролю ознаки кількість зерен в колосі разом з генами, що виявляють адитивну дію, значний внесок вносять гени з домінантною дією. При цьому домінантні ефекти проявляються в більшій мірі, ніж, наприклад, за кількістю колосків в колосі або довжиною колоса. Показник успадковуваності за кількістю колосків та зерен з колоса знаходився в межах від 0,19 до 0,77 та від 0,22 до 0,51.

Говорячи про масу зерна 3 колоса, деякі автори [279] визначили тенденцію вираження високої маси зерна з колоса домінуючими генами. Адитивні і домінуючі ефекти для цієї ознаки визначали М. M. El-Haddod [20] і R. S. Paroda [21]. Інші дослідники [22] відмічають, що маса зерна 3 колоса контролюється в основному генами з адитивною дією. При цьому гени з домінантними ефектами та ефектами наддомінування відіграють значно меншу роль. На думку деяких вчених [23, 24], навпаки, домінування та наддомінування відіграють більш істотну роль при вираженні даної ознаки у гібридів. 
Успадкування елементів продуктивності колоса у внутрішньовидових гібридів $\mathrm{F}_{2}$ пшениці твердої ярої (МІП, 2014 р.)

\begin{tabular}{|l|c|c|c|c|}
\hline \multicolumn{1}{|c|}{ Комбінація схрещування } & $\begin{array}{c}\text { Довжина } \\
\text { колоса }\end{array}$ & $\begin{array}{c}\text { Кількість } \\
\text { колосків } \\
\text { у колосі }\end{array}$ & $\begin{array}{c}\text { Кількість } \\
\text { зерен 3 } \\
\text { колоса }\end{array}$ & $\begin{array}{c}\text { Маса } \\
\text { зерна 3 } \\
\text { колоса }\end{array}$ \\
\hline Харківська 27 х Neоdur & $0,76 / 0,58$ & $0,19 / 0,24$ & $0,40 / 0,44$ & $0,60 / 0,41$ \\
\hline Леукурум 02-03 х Леукурум 99-06 & $0,61 / 0,58$ & $0,21 / 0,31$ & $0,47 / 0,36$ & $0,48 / 0,25$ \\
\hline Ізольда х Леукурум 99-06 & $0,58 / 0,64$ & $0,73 / 0,68$ & $0,37 / 0,41$ & $0,57 / 0,61$ \\
\hline Леукурум 06-07 х Харківська 29 & $0,54 / 0,47$ & $0,61 / 0,37$ & $0,45 / 0,37$ & $0,35 / 0,37$ \\
\hline Чадо х Леукурум 02-03 & $0,51 / 0,47$ & $0,47 / 0,48$ & $0,42 / 0,35$ & $0,57 / 0,47$ \\
\hline Лінія 10-04 х Аmmar 9 & $0,49 / 0,54$ & $0,54 / 0,37$ & $0,31 / 0,24$ & $0,47 / 0,35$ \\
\hline Леукурум 02-03 х Славута & $0,48 / 0,51$ & $0,68 / 0,57$ & $0,41 / 0,38$ & $0,61 / 0,58$ \\
\hline Леукурум 05-20 х Славута & $0,47 / 0,37$ & $0,51 / 0,47$ & $0,47 / 0,33$ & $0,47 / 0,38$ \\
\hline Спадщина х Лінія 10-01 & $0,47 / 0,41$ & $0,48 / 0,44$ & $0,48 / 0,35$ & $0,51 / 0,47$ \\
\hline Саратовская золотистая х Nеодиг & $0,46 / 0,51$ & $0,53 / 0,38$ & $0,51 / 0,55$ & $0,77 / 0,81$ \\
\hline Харківська 37 х Лінія 10-01 & $0,32 / 0,41$ & $0,35 / 0,43$ & $0,24 / 0,33$ & $0,31 / 0,44$ \\
\hline МІП Райдужна х Аттаг 9 & $0,30 / 0,43$ & $0,13 / 0,24$ & $0,24 / 0,37$ & $0,17 / 0,23$ \\
\hline Харківська 27 х Леукурум 99-06 & $0,28 / 0,37$ & $0,66 / 0,71$ & $0,48 / 0,45$ & $0,66 / 0,74$ \\
\hline Леукурум 06-07 х Саратовская золотистая & $0,17 / 0,28$ & $0,77 / 0,84$ & $0,22 / 0,38$ & $0,41 / 0,48$ \\
\hline
\end{tabular}

Примітка: у чисельнику - коефіцієнт успадковуваності $\left(\mathrm{H}^{2}\right)$ у широкому розумінні; у знаменнику - коефіцієнт успадковуваності $\left(\mathrm{h}^{2}\right)$ у вузькому розумінні

Що стосується ступеня успадковуваності даної ознаки, то тут також немає єдиної думки. Якщо в працях одних вчених відмічається високий ступінь успадковуваності [14], то інші вказують на низьку успадковуваність ознаки [25]. Показник успадковуваності за масою зерна 3 колоса варіював від 0,17 до 0,77 залежно від походження комбінації.

Таким чином, в другому поколінні ми отримали дуже різноманітний матеріал за проявом ознак, що вивчали. Загальна оцінка отриманих результатів свідчить про широкий розмах мінливості ознак продуктивності у гібридів пшениці твердої ярої.

Висновки. Успадковування ознак продуктивності внутрішньовидових гібридів $\mathrm{F}_{2}$ виявилося наступним: за кількістю колосків у колосі $\left(\mathrm{H}^{2}=0,19-0,77\right)$, масою зерна 3 колоса $\left(\mathrm{H}^{2}=0,17-0,77\right)$, довжиною колоса $\left(\mathrm{H}^{2}=0,17-0,76\right)$, кількістю зерен з колоса $\left(\mathrm{H}^{2}=0,22-0,51\right)$. Таким чином, загальний аналіз спадковості у гібридів $F_{2}$ свідчить про складну генетичну детермінацію ознак продуктивності, що залежить від взаємодії багатьох спадкових чинників обох батьківських компонентів і умов вирощування.

\section{Список використаних джерел}

1. Ригер, Р. Генетический и цитологический словарь [Текст] / Р. Ригер, А. Михаэлис. - Москва: Колос. - 1967. - 607 с.

2. Орлюк, А. П. Трансгрессивная изменчивость у озимой пшеницы и ее использование в селекции [Текст] / А. П. Орлюк // Генетика. - 1976. - Т. 12, № 2. - С. 15-24.

3. Лукьяненко, П. П. Основные итоги работ по селекции озимой пшеницы на Кубанской сельскохозяйственной опытной станции [Текст] / П. П. Лукьяненко // Изб. тр. - Москва: Колос. - 1973. - С. 11-13.

4. Дубинин, Н. П. Общая генетика [Текст] / Н. П. Дубинин. - Москва: Наука. - 1976. $590 \mathrm{c.}$

5. Мюнтцинг, А. Генетика [Текст] / А. Мюнтцинг. - Москва: Мир. - 1967. - 610 с.

6. Уильямс, У. Генетические основы и селекция растения [Текст] / У. Уильямс. - Москва: Колос. - 1968. - $448 \mathrm{c.}$

7. Орлюк, А. П. Принципы трансгрессивной селекции пшеницы [Текст] / А. П. Орлюк, В. В. Базалій. - Херсон: типография изд-ва „Наддніпрянська правда”, 1998. - 274 с. 
8. Mahmud, I. Segregation for yield, height and maturity following a soybean cross [Text] / I. Mahmud, H. Kramer // Agron. S. - 1951. - Vol. 43, № 12. - P. 605-609.

9. Жученко, А. А. Экологическая генетика культурных растений [Текст] / А. А. Жученко. Кишенев: Штиинца, 1980. - 588 с.

10. Воскресенская, Г. С. Трансгрессия признаков у гибридов Brassica, методика количественного учета этого явления [Текст] / Г. С. Воскресенская, В. И. Шпота // Доклады ВАСХНИЛ, 1967. - № 7. - С. 18-19.

11. Рябченко, О. М. Створення вихідного матеріалу для адаптивної селекції озимої м'якої пшениці в умовах південно-східної частини Степу України [Текст] : Автореф. дис...канд. с.-г. наук: 06.01.05. / О. М. Рябченко. - Дніпропетровськ, 2006. - 16 с.

12. Седловский, А. И. Генетико-статистические подходы к теории селекции самоопыляющихся культур [Текст] / А. И. Седловский, С. П. Мартынов, Л. К. Мамонов. - АлмаАта: Наука, 1982. - 200 c.

13. Walton, P. D. Inheritance of morphological characters associated with yield in spring wheat [Text] / P. D. Walton // Canad. J. Plant Sci. - 1969. - V. 49, № 5. - P. 587-596.

14. Рейтер, Б. Г. Наследуемость некоторых количественных признаков и генетический эффект отбора в гибридных популяциях яровой пшеницы [Текст] / Б. Г. Рейтер, С. И. Леонтьев // Сибирский вестник с.-х. науки. - 1972. - № 2. - С. 44-49.

15. Ibrahim, A. Variability of character expression in barley $\mathrm{M}_{3}$ and $\mathrm{M}_{4}-$ balk populations after seed irradiation with gamma rays [Text] / A. Ibrahim, A. Sharean // Leitschrift fur pflanzenzuchtung. - 1974. - V. 72, № 3. - S. 212-225.

16. Rajinde,r K. Heritability and genetic advance of some quantitative characters in crosses of wheat (Triticum aestivum L.) [Text] / K. Rajinder, S.C. Anand, D. S. Virk // J. Res. - 1972. V. 9, № 4. - P. 515-523.

17. Димова, Р. Хетерозис при пшеницата [Текст] / Р. Димова. - Науч. тр. Высш. селскостоп. ин-т. - Болгария, Димитров, 1968. - № 19. - С. 127-133.

18. Лубнин, А. Н. Гетерозис и наследование основных признаков в $F_{1}$ от скрещивания некоторых сортов озимой пшеницы [Текст] / А. Н. Лубнин // Бюллетень ВИР. - Вып. 32. C. $10-14$.

19. Wegrzyn, S. Wartosc kombinacyjna i sposoby dzialania genow dla kilku cech odmian i mieszancow pszenicy ozimej [Text] / S. Wegrzyn, L. Pochaba // Hod. Rosl. Aklim. - 1980. V. 24, № 3. - P. 211-224.

20. Цильке, Р. А. Изменчивость генетических параметров при диаллельном анализе количественных признаков мягкой яровой пшеницы. Сообщение 3. Длина колоса [Текст] / Р. А. Цильке, О. Т. Качур, С. А. Садыкова // Генетика. - 1979. - Т. 15, № 2. - С. 286-297.

21. Paroda, R. S. Diallel analysis for plant height in wheat [Text] / R. S. Paroda // Cereal Res. Comm. -1974. - V. 2. - P. 147-157.

22. Brown, C. M. Heterosis and combining abiliti in common wheat [Text] / C. M. Brown, R. O. Weibel, R. D. Seif // Crop. Sci. - 1966. - V. 6, № 6. - P. 382-385.

23. Усикова, А. Наследование некоторых качественных и количественных признаков в системе диаллельных скрещиваний ячменя [Текст] / А. Усикова // Цитология и генетика. 1978. - T. II, № 5. - C. 417-428.

24. Sun, P. L. Inheritance of kernel weight in six spring wheat crosses [Text] / P. L. Sun, H. L. Shands, R. A. Forsbers // Cros. Sci. - 1972. - V. 12, № 1. - P. 1-19.

25. Цильке, Р. А. Изучение наследования количественных признаков у мягкой яровой пшеницы в топкроссных скрещиваниях. Сообщение 4. Число колосков в колосе [Текст] / Р. А. Цильке // Генетика. - 1977. - Т. 13, № 3. - С. 396-406. 


\section{References}

1. Riger R, Mykhaelis A. Genetic and cytological dictionary. Moscow: Kolos. 1967. 607 p.

2. Orliuk AP. Transgressive variability of winter wheat and its use in breeding. Genetika. 1976; 12(2) : 15-24.

3. Lukyanenko, PP. Major outcomes of winter wheat breeding at the Kuban Agricultural Experiment Station. Moscow: Kolos. 1973. P. 11-13

4. Dubinin, NP. General Genetics. Moscow: Nauka. 1976. 590 p.

5. Muntzing, A. Genetics. Moskva: Mir. 1967. 610 p.

6. Williams, W. Genetic basis and plant breeding. Moskva: Kolos. 1968. 448 p.

7. Orliuk AP, Bazaliy VV. Principles of transgressive wheat breeding. Kherson: Naddnipryanska pravda. 1998. $274 \mathrm{p}$.

8. Mahmud I, Kramer H. Segregation for yield, height and maturity following a soybean cross. Agron. S. 1951; 43(12): 605-609.

9. Zhuchenko, AA. Ecological genetics of cultivated plants. Kishinev: Shtiintsa. 1980. 588 p.

10. Voskresenskaia GS, Shpota VI. Transgression of traits in Brassica hybrids: a method for quantifying this phenomenon. Reports of Academy of Agricultural Sciences. 1967; 7: 18-19.

11. Riabchenko, OM. Creation of source material for adaptive breeding of winter wheat in the South-Eastern Steppe of Ukraine. Dnipropetrovsk. 2006. 16 p.

12. Sedlovskiy AI, Martynov SP, Mamonov LK. Genetic and statistical approaches to the theory of breeding self-pollination plants. Alma-Ata: Nauka; 1982. 200 p.

13. Walton PD. Inheritance of morphological characters associated with yield in spring wheat. Canad. J. Plant Sci. 1969; 49(5): 587-596.

14. Reiter BG, Leontiev SI. Heritability of some quantitative traits and genetic effect of selection in hybrid populations of spring wheat. Siberian Bulletin of agricultural science. 1972; 2: 44-49.

15. Ibrahim A, Sharean A. Variability of character of expression in barley $\mathrm{M}_{3}$ and $\mathrm{M}_{4}-$ balk populations after seed irradiation with gamma rays. Leitschrift fur pflanzenzuchtung. 1974; 72(3): 212-225.

16. Rajinder K, Anand SC, Virk DS. Heritability and genetic advance of some quantitative characters in crosses of wheat (Triticum aestivum L.). J. Res. 1972; 9(4): 515-523.

17. Dimova, R. Heterozis pri pshenitsata. Nauch. tr. Vyssh. selsko-stop. int. Bulgaria. Dimitrov 1968; 19: 127-133.

18. Lubnin, AN. Heterosis and inheritance of major traits in $\mathrm{F}_{1}$ from crossing some winter wheat varieties. Bulletin VIR. 32: 10-14.

19. Wegrzyn S, Pochaba L. Wartosc kombinacyjna i sposoby dzialania genow dla kilku cech odmian i mieszancow pszenicy ozimej. Hod. Rosl. Aklim. 1980; 24(3): 211-224.

20. Zielke RA, Kachur OT, Sadykova SA. Variability of genetic parameters in diallel analysis of quantitative traits of soft spring wheat. Report 3. Ear length. Genetika. 1979; 15(2): 286-297.

21. Paroda RS. Diallel analysis for plant height in wheat. Cereal Res. Comm. 1974; 2: 147-157.

22. Brown CM, Weibel RO, Seif RD. Heterosis and combining ability in common wheat. Crop. Sci. 1966; 6(6): 382-385.

23. Usikova A. Inheritance of some qualitative and quantitative traits in diallel barley. Cytol. and Genet. 1978; II (5): 417-428.

24. Sun PL, Shands HL, Forsbers RA. Inheritance of kernel weight in six spring wheat crosses. Cros. Sci. 1972; 12(1): 1-19.

25. Zielke RA. Study of inheritance of quantitative traits in soft spring wheat in top-crosses. Report 4. Spikelet number per ear. . Genetika. 1977; 13(3): 396-406. 


\section{ТРАНСГРЕССИВНАЯ ИЗМЕНЧИВОСТЬ ПРИЗНАКОВ ПРОДУКТИВНОСТИ ГИБРИДОВ ВТОРОГО ПОКОЛЕНИЯ ПШЕНИЦЫ ТВЕРДОЙ ЯРОВОЙ}

Хоменко С. О., Федоренко М. В.

Мироновский институт пшеницы имени В. Н. Ремесло НААН, Украина

Цель и задача исследования предусматривала изучение характера наследования признаков продуктивности растений во втором поколении гибридов пшеницы твердой яровой.

Материалы и методика. Исследования проводились в течение 2014 г. в условиях опытного поля лаборатории селекции яровой пшеницы Мироновского института пшеницы имени В. Н. Ремесло НААН Украины. Материалом для исследования служили 10 сортов и семь константных линий гибридного происхождения пшеницы твердой яровой различного генетического происхождения с разным адаптивным потенциалом. На их основе создано 14 гибридных комбинаций $\mathrm{F}_{2}$, которые получены в результате внутривидовой гибридизации. Коэффициенты наследуемости признаков в широком смысле определяли через вариансы родителей и гибридов, в узком - находили через коэффициенты корреляции между родителями и потомками. Степень и частоту положительной трансгрессии рассчитывали по методике Воскресенской-Шпота.

Обсуждение результатов. $\mathrm{B} \mathrm{F}_{2}$ выделены вероятны трансгрессивные формы внутривидовых гибридов пшеницы твердой яровой, которые могут в дальнейшем быть исходным материалом для отбора настоящих трансгрессивных форм в более поздних поколениях. Более высокие показатели коэффициента наследуемости выявлены по признакам „количество колосков в колосе”, „масса зерна с колоса”, „длина колоса”, в частности в комбинациях: Харьковская 27 х Neodur, Леукурум 02-03 х Леукурум 99-06, Изольда х Леукурум 99-06, Леукурум 06-07 х Харьковская 29, Чадо х Леукурум 02-03, что свидетельствует об эффективности отбора по этим показателям.

Выводы. Наследование признаков продуктивности у внутривидовых гибридов $\mathrm{F}_{2}$ оказалось следующим: по количеству колосков в колосе $\left(\mathrm{H}^{2}=0,19-0,77\right)$, массе зерна с колоса $\left(\mathrm{H}^{2}=0,17-0,77\right)$, длине колоса $\left(\mathrm{H}^{2}=0,17-0,76\right)$, количеству зерен с колоса $\left(\mathrm{H}^{2}=0,22\right.$ $0,51)$. Таким образом, анализ наследственности у гибридов $F_{2}$ свидетельствует о сложной генетической детерминации признаков продуктивности, зависит от взаимодействия многих наследственных факторов обоих родительских компонентов и условий возделывания.

Ключевые слова: пшенища твердая яровая, трансгрессия, продуктивность, гибрид

\section{TRANSGRESSIVE VARIABILITY OF PRODUCTIVITY TRAITS OF DURUM SPRING WHEAT F ${ }_{2}$ HYBRIDS}

Khomenko S. O., Fedorenko M. V.

The V. M. Remeslo Myronivka Institute of Wheat of NAAS, Ukraine

The aim and tasks of the study included studying inheritance of plant productivity traits in durum spring wheat $\mathrm{F}_{2}$ hybrids.

Material and Methods. The investigations were conducted in 2014 in the experimental field of the Laboratory of Spring Wheat Breeding of the V. M. Remeslo Myronivka Institute of Wheat of NAAS of Ukraine. 10 durum spring wheat varieties and 7 constant hybrid lines of different genetic origin with different adaptive potential served as the test material. On their basis $14 \mathrm{~F}_{2}$ hybrid combinations were obtained by intraspecific hybridization. Coefficients of heritability of traits in the broad sense were determined by variances of parents and hybrids, in the narrow sense - through correlation coefficients between parents and progenies. Degree and frequency of positive transgression were calculated by Voskresenskaya and Shpota.

Results and Discussion. Probable transgressive forms of intraspecific hybrids of durum spring wheat, which can be further used as source material for selection of real transgressive forms in 
later generations, were identified in $\mathrm{F}_{2}$. Higher values of the heritability coefficient were detected for the traits of "spikelet number per ear", "grain weight per ear" "ear length", in particular in the following combinations: Kharkivs'ka 27 x Neodur, Leucurum 02-03 x Leucurum 99-06, Izol`da x Leucurum 99-06, Leucurum 06-07 x Kharkivs`ka 29, Chado x Leucurum 02-03, that attests to efficiency of selection by these parameters.

Conclusions. Inheritance of productivity traits in intraspecific $\mathrm{F}_{2}$ hybrids was the following: the spikelet number per ear $\left(\mathrm{H}^{2}=0.19-0.77\right)$, grain weight per ear $\left(\mathrm{H}^{2}=0.17-0.77\right)$, ear length $\left(\mathrm{H}^{2}=0.17-0.76\right)$, grain number per ear $\left(\mathrm{H}^{2}=0.22-0.51\right)$. Thus, analysis of heredity in $\mathrm{F}_{2}$ hybrids indicates that genetic determination of productivity traits is complex and depends on interactions between many hereditary factors of both parental components and growing conditions.

Key words: durum spring wheat, transgression, productivity, hybrid

УДК 633.11:631.527

\section{КОЕФЦЦЕНТИ КОРЕЛЯЦЇ̈ ТА ДЕТЕРМІНАЦЇ̈ МІЖ ОЗНАКАМИ СОРТІВ ПШЕНИЦІ М'ЯКӦ̈ ОЗИМӦ̈}

Четверик О. О., Козаченко М. Р.

Інститут рослинництва ім. В. Я. Юр'єва НААН, Україна

Наведено результати дослідження в 2012-2014 рр. у лабораторії селекції і фізіології озимої пшениці Інституту рослинництва ім. В. Я. Юр'єва НААН зв'язків між параметрами кількісних ознак 14 сортів пшениці м'якої озимої різного географічного походження за множинними та парними коефіцієнтами кореляції та частки мінливості за коефіцієнтами детермінації. Установлено особливості множинних коефіцієнтів кореляції $(\mathrm{R})$ та детермінації (D) між трьома ознаками рослин при визначенні рівня зв'язку між однією з ознак і сукупним впливом двох інших ознак за парними коефіцієнтами кореляції (r) та детермінації (d). Найвищими множинні коефіцієнти кореляції та детермінації були між ознакою продуктивність рослин $(\mathrm{R}=0,92$ i $\mathrm{D}=0,85)$ і сукупним впливом ознак продуктивна кущистість (при $\mathrm{r}=0,81 \mathrm{i} \mathrm{d}=0,66)$ i маса зерна 3 колосу (при $\mathrm{r}=$ $0,55 \mathrm{i} \mathrm{d}=0,30)$. Високим був множинний зв'язок між ознакою маса зерна 3 колосу $(\mathrm{R}=$ $0,92$ i $\mathrm{D}=0,85)$ і сукупним впливом кількості зерен з колосу $(\mathrm{r}=0,68 \mathrm{i} \mathrm{d}=0,46)$ та маси 1000 зерен $(\mathrm{r}=0,63 \mathrm{i} \mathrm{d}=0,40)$. Зв'язки між іншими ознаками як за множинними, так і за парними коефіцієнтами кореляції (і детермінації) були середніми та низькими і недостовірними.

Ключові слова: пшениця м'яка озима, сорт, кількісна ознака, парний та множинний коефіиієнт, кореляція, детермінація

Вступ. У селекції сільськогосподарських культур, зокрема пшениці м'якої озимої, важливе значення має визначення особливостей вихідного матеріалу за рівнем та мінливістю кількісних ознак рослин, а також за взаємозв'язками між ними [1]. Ефективність селекційного використання вихідних форм у значній мірі залежить від знання залежності основної ознаки, за якою проводять добір, від рівня та мінливості інших ознак рослин [2]. У зв'язку з цим актуальним є дослідження кореляцій між кількісними ознаками рослин та визначення частки мінливості, яка залежить від впливу однієї ознаки на іншу [3].

(C) О. О. Четверик, М. Р. Козаченко. 2015.

ISSN 0582-5075. Селекція і насінництво. 2015. Випуск 107. 